\title{
The Impact of Genetic Changes during Crop Domestication
}

\author{
Petr Smýkal 1,*(iD, Matthew N. Nelson ${ }^{2,3}$, Jens D. Berger ${ }^{4}$ and Eric J.B. von Wettberg ${ }^{5}$ (iD) \\ 1 Department of Botany, Palacky University, 78301 Olomouc, Czechia \\ 2 Natural Capital and Plant Health, Royal Botanic Gardens Kew, Wakehurst Place, Ardingly, \\ West Sussex RH17 6TN, UK; M.Nelson@kew.org \\ 3 UWA Institute of Agriculture and School of Agriculture and Environment, \\ The University of Western Australia, Perth, WA 6009, Australia \\ 4 CSIRO Agriculture and Food, Wembley, WA 6913, Australia; Jens.Berger@csiro.au \\ 5 Department of Plant and Soil Science, University of Vermont, Burlington, VT 05405, USA; \\ ebishopv@uvm.edu \\ * Correspondence: petr.smykal@upol.cz; Tel.: +420-585-634-827
}

Received: 11 June 2018; Accepted: 12 July 2018; Published: 14 July 2018

Abstract: Humans have domesticated hundreds of plant and animal species as sources of food, fiber, forage, and tools over the past 12,000 years, with manifold effects on both human society and the genetic structure of the domesticated species. The outcomes of crop domestication were shaped by selection driven by human preferences, cultivation practices, and agricultural environments, as well as other population genetic processes flowing from the ensuing reduction in effective population size. It is obvious that any selection imposes a reduction of diversity, favoring preferred genotypes, such as nonshattering seeds or increased palatability. Furthermore, agricultural practices greatly reduced effective population sizes of crops, allowing genetic drift to alter genotype frequencies. Current advances in molecular technologies, particularly of genome sequencing, provide evidence of human selection acting on numerous loci during and after crop domestication. Population-level molecular analyses also enable us to clarify the demographic histories of the domestication process itself, which, together with expanded archaeological studies, can illuminate the origins of crops. Domesticated plant species are found in 160 taxonomic families. Approximately 2500 species have undergone some degree of domestication, and 250 species are considered to be fully domesticated. The evolutionary trajectory from wild to crop species is a complex process. Archaeological records suggest that there was a period of predomestication cultivation while humans first began the deliberate planting of wild stands that had favorable traits. Later, crops likely diversified as they were grown in new areas, sometimes beyond the climatic niche of their wild relatives. However, the speed and level of human intentionality during domestication remains a topic of active discussion. These processes led to the so-called domestication syndrome, that is, a group of traits that can arise through human preferences for ease of harvest and growth advantages under human propagation. These traits included reduced dispersal ability of seeds and fruits, changes to plant structure, and changes to plant defensive characteristics and palatability. Domestication implies the action of selective sweeps on standing genetic variation, as well as new genetic variation introduced via mutation or introgression. Furthermore, genetic bottlenecks during domestication or during founding events as crops moved away from their centers of origin may have further altered gene pools. To date, a few hundred genes and loci have been identified by classical genetic and association mapping as targets of domestication and postdomestication divergence. However, only a few of these have been characterized, and for even fewer is the role of the wild-type allele in natural populations understood. After domestication, only favorable haplotypes are retained around selected genes, which creates a genetic valley with extremely low genetic diversity. These "selective sweeps" can allow mildly deleterious alleles to come to fixation and may create a genetic load in the cultivated gene pool. Although the population-wide 
genomic consequences of domestication offer several predictions for levels of the genetic diversity in crops, our understanding of how this diversity corresponds to nutritional aspects of crops is not well understood. Many studies have found that modern cultivars have lower levels of key micronutrients and vitamins. We suspect that selection for palatability and increased yield at domestication and during postdomestication divergence exacerbated the low nutrient levels of many crops, although relatively little work has examined this question. Lack of diversity in modern germplasm may further limit our capacity to breed for higher nutrient levels, although little effort has gone into this beyond a handful of staple crops. This is an area where an understanding of domestication across many crop taxa may provide the necessary insight for breeding more nutritious crops in a rapidly changing world.

Keywords: domestication; crops; crop wild relatives; genetic diversity

\section{Introduction}

Humans have domesticated hundreds of plant and animal species as sources of food, fiber, forage, and tools over the past 12,000 years [1], with manifold effects on both human society and the genetic structure of the domesticated species. The history of agriculture can be viewed as a series of key events: the Neolithic Revolution, the Columbian Exchange, the Industrial Revolution, the Green Revolution, and subsequent genomic revolutions. Each of these had positive effects, but they have also come at a cost, such as the substantial reduction in agricultural biodiversity [2]. For example, the landfall of the European explorer Christopher Columbus in the Americas (1492) triggered the largest exchange of agricultural biodiversity in history, or the Green Revolution that resulted in the reduction of crop diversity in favor of a high yielding major cereal crops typically grown in monocultures.

The process of crop domestication is driven by human selection, cultivation practices, and agricultural environments. Any selection imposes the reduction of diversity in genomic regions controlling desirable traits, such as nonshattering seeds or increased palatability. Furthermore, agricultural practices greatly reduced effective population sizes of crops, allowing genetic drift to alter genotype frequencies, including the random loss of alleles [3-5]. Current advances in molecular technologies, particularly of genome sequencing, provide evidence of human selection acting on numerous loci during and after crop domestication [6]. Population-level molecular analyses also enable us to clarify the demographic histories of the domestication process itself, which, together with expanded archaeological studies, can illuminate the origins of crops [7].

\subsection{Domesticated Crops Are a Subset of World Plant Diversity}

It is estimated that on the earth, there are between 370,000 and 500,000 species of higher plants, of which approximately 369,000 have been described [8]. Many species are still unknown to science, while perhaps a third is at risk of extinction [9]. At present, the Angiosperm Phylogeny Group [10] recognizes 462 families of flowering plants (angiosperms).

\begin{tabular}{|c|c|}
\hline Family & Number of Species \\
\hline Asteraceae (daisies) & 32,581 \\
\hline Orchidaceae (orchids) & 28,237 \\
\hline Fabaceae (legumes) & 20,856 \\
\hline Rubiaceae (coffees) & 13,686 \\
\hline Poaceae (grasses) & 11,430 \\
\hline
\end{tabular}

The largest families of gymnosperms (12 families, 1110 species, conifers, cycads) are the Zamiaceae (a group of cycads containing 232 species) and Pinaceae (pines, containing 231 species). 
Given that most plant species living today are likely to have existed for millions of years, our human ancestors would have known and used many of them for tens to hundreds of thousands of years. However, our present knowledge of domesticated plants largely reflects our experience of a relatively small number of living domesticates adapted to recent, Holocene environments. The number of plant species used for food by preagricultural human societies is estimated to be around 7000, of which only a tiny fraction were domesticated [11]. Although archaeological evidence indicates the beginning of agriculture from the late Pleistocene and early Holocene onward, human interactions with plants that are now domesticated are likely to have started much earlier [12], establishing traditions and archetypic views of plants that remain today. Although human dietary habits are rather plastic [13], most people in each society follow established food traditions, making adjustments only when necessary. Classical examples are potato and tomato, introduced to Europe in the 1500s, both met with suspicion and regarded as poisonous due to their relationship to the deadly Old World relatives (Atropa, Hyoscyamus sp.). They were first cultivated as ornamental curiosities in Europe for nearly three centuries before ultimately finding acceptance as important foods. Our ability to organize information and recognize archetypes is linked to the physiological reward system that gives us pleasure when finding something for which we have been consciously searching. Levitin [14] proposed that the human brain has been configured to acquire information about the biological world, and that we have an innate passion for naming and categorizing plants.

Domesticated plant species are found in more than 160 taxonomic families [1]. The most important of these are Poaceae, Fabaceae, and Brassicaceae. Approximately 2500 species have undergone some degree of domestication, but only 250 are considered to be fully domesticated [1]. Many of these have only minor use in particular regions or on specific occasions. Instead, humanity relies on a small collection of crop plants for the majority of our dietary intake. Indeed, $<20$ plant species together provide about $95 \%$ of the world's calorie intake. These include bananas/plantains, beans, cassava, maize, millet, potatoes, rice, sorghum, soybean, sugar cane, sweet potatoes, wheat, and legumes such as lentil, pea, and chickpea [15]. This concentration on a few food species is a key element of the vulnerability of the world food supply to the impact of climate change and the outbreak of major new plant diseases and pests. With so few species grown as staples, there is greater potential for epidemic outbreaks of disease and pests.

\subsection{Centers of Crop Origin and Domestication Speed}

Biological diversity is not evenly distributed either geographically or biologically. The hypothesis that crop plants were domesticated in the centers of respective species diversity was initially proposed by Alfonse de Candolle [16] and refined and expanded by Nikolai I. Vavilov [17]. Biologically, genetic diversity is distributed over primary, secondary, and tertiary gene pools [18], defined by their hybridization compatibility, and therefore not equally accessible to domesticated crops. Finally, within a genome, genetic diversity is also unequally distributed along chromosomes and is positively correlated with the level of recombination [19].

Recently there has been considerable debate on domestication as a centric/punctuated process in the cradle of agriculture [20-22] versus multiple origins over protracted time periods [23-25]. Indeed, domesticated crops could have single or multiple origins, linear or reticulate descent from an ancestral population(s), with gene flow within and between wild and domesticated populations throughout the evolution of the crop. There appears to be evidence for all these possibilities among our domesticated crops. Chickpea is thought to have a monophyletic origin, given the narrow distribution of its wild progenitor [26] and the limited genetic diversity of the cultigen [7,27]. Domesticated barley (Hordeum vulgare) [28,29] and emmer wheat (Triticum turgidum L.) [23] have more polyphyletic tendencies. Both show traces of mosaic eastern and western ancestral origins from opposite ends of the Near Eastern Fertile Crescent. While these regions clearly lie outside a discretely defined core area [21], they do occur within "interacting socio-cultural spheres" [22], making it difficult to be certain about their independent, polyphyletic origin. Apple (Malus domestica) was domesticated 4000-10,000 ybp 
from M. sieversi in the Central Asian Tian Shan mountains and moved to Europe along the Silk Road, hybridizing bidirectionally with wild relatives (M. orientalis, $M$. sylvestris) at different time points on route [30]. Apple has a self-incompatibility mechanism that ensures outbreeding, facilitating these domestic-wild interactions [30]. Finally, domesticated rice (Oryza sativa L.) has the strongest evidence for polyphyletic origins, with independent, spatially separate domestication in China (japonica gene pool), Indochina to Brahmaputra valley (indica gene pool), and central India to Bangladesh (aus gene pool) [31,32]. Subsequently, there was geneflow between each of these genepools, which may [32] or may not [33] be responsible for the introgression of domestication syndrome traits from the japonica to the indica pool.

There have been numerous attempts to determine the speed of the domestication process. Multiple methods have been used to ask this question, including forward-in-time simulations [34], coalescent simulations [35], and selection experiments [36]. Nevertheless, clarifying the intricate and conflicted record remains challenging. Although empirical studies indicate that selection might be rapid, the archaeological evidence indicates a slower process over millennia. Because the historical record is fragmented and incomplete, archaeological evidence provides a porous lower boundary on how and where early domestication may have started (approximately 10-12 thousand years ago). Finally, there is a long standing discussion on the relative roles of conscious (intentional selection for a trait) or unconscious selection (selection that occurs as a by-product of farming systems) [20,37]. These are open questions that are being addressed at a range of biological scales as discussed below.

\subsection{Domestication Has Left Signatures Both on Morphological as well as Molecular Levels}

Domestication helped Charles Darwin to explain evolution, as he used artificial selection examples that would have been widely known to 19th century readers persuasively in the first chapter of On the Origin of Species [38]. However, new insights into evolutionary processes have also contributed to our understanding of domestication $[12,39,40]$.

The evolutionary trajectory from wild to crop species is a complex process. Archaeological records suggest that there was a period of predomestication cultivation while humans first began the deliberate planting of wild stands that have favorable traits. This human-associated cultivation reshaped the evolutionary trajectories of these species to become transformed into domesticated crops. These crops evolved over time and space as they spread to new areas (e.g., chickpea [41]), sometimes beyond the climatic niche of their wild relatives [7,42]. However, the speed and level of human intentionality during domestication remain topics of discussion [42,43]. It is commonly considered that at first there was wild harvesting, followed by conscious and unconscious selection to modify plant characteristics, and finally conscious selection of plant material for specific locations and uses, with the plant generally losing the ability to survive without human care [44]. A contrary opinion is that domestication may have occurred more intentionally, and that in the case of legumes, they may have had some domestication traits before they were cultivated [20].

All crop plants have been domesticated from wild relatives. The wild species from which a crop plant was derived in some cases may be well known and easily identified in current wild plant populations, while others have arisen via hybridization and polyploidization [45-47]. Based on reproductive isolation, the concept of genepools has been established [18], where the closest crop wild relatives that are fully interfertile with the crop species represent an easily accessible or primary gene pool for crop improvement, while more distant relatives from which genes can be accessed with increasing degrees of difficulty form secondary and tertiary gene pools.

Indeed, the development of reproductive barriers is closely associated with successful domestication [48], although it is not clear whether it is a cause or a consequence of domestication. On the one hand, reproductive isolation of the crop from its wild progenitor ensures that domesticated traits are not continuously diluted by introgression of wild alleles, facilitating the selection of ever-more domesticated crops. A good example of this is the development of narrow-leafed lupin (Lupinus angustifolius L.), where the selection of increasingly early, vernalization-insensitive cultivars, 
which has increased harvest index and yield potential in short season environments [49,50], has been facilitated by reproductive isolation from its wild, vernalization-responsive progenitor. This is possible because: (a) of low outcrossing rates; (b) wild L. angustifolius tends not to be sympatric with narrow-leafed lupin production areas; and (c) the domestication syndrome traits of Australian cultivars were linked with white flowers and seeds by Gladstones [51], contrasting with the blue flowers and mottled seeds of the wild relatives. When there is no reproductive isolation, and wild-domestic hybrids are indistinguishable from domestic, it can be difficult to sustain ongoing domestication. This is well illustrated by grasspea (Lathyrus satious L.), where high outcrossing rates among sympatric populations and natural selection for the toxic, wild-type high-ODAP variant make it very difficult to maintain "sweet" cultivars in production systems despite their availability since the mid-1970s [52,53]. Conversely, it must be recognized that the introduction of wild progenitors to novel agricultural ecosystems has driven unique adaptations. For example, introgression of primary gene pool wild Cicer species has improved both nematode and phytophthora resistance of Australian chickpea cultivars [54,55].

Molecular analyses have demonstrated that convergent phenotypic evolution is often based on molecular changes in orthologous genes or pathways. Although domestications have occurred separately on different continents and in different cultural traditions, representing thus a set of parallel experiments from which to infer recurrent processes, plants have been subjected to similar selection pressures and developed identical or similar adaptations in different places, leading to convergent evolution [56]. Actually, Vavilov [57] had posited the Law of Homologous Variation, stating that closely related species and genera are characterized by similar homologous series in their genetic variability. This observation is consistent with the concept of domestication syndrome as well as the view of convergent evolution. Lenser and Theißen [56] applied a view of "molecular convergence" to look at plant domestication. There are many examples that show that molecular convergence indeed plays an important role during domestication [58,59]. Orthologous genes and loss-of-function mutations in the YABBY transcription factor Shattering1 (Sh1) for reduced seed shattering have been identified in several grain crops, including sorghum, maize, rice [60], and wheat [61]. Similarly, loss of function of TERMINAL FLOWER1 (TFL1) orthologues is observed to underlie determinant growth habit of inflorescence in a number of crop species, suggesting that artificial selection for determinacy is highly convergent at this gene (in the common bean [62] and pigeon pea [63]). Flowering time control also plays important role in crops, and thus not surprisingly, central genes appear to be recurrent targets of artificial selection. Particularly, the flowering inducer FT has been shown to have an important role in the domestication and diversification of both monocot and eudicot crops (sunflower [64], soybean [65], rice [66], lupin [67], and chickpea [7]).

Although there are examples of orthologous genes having been responsible for similar phenotypes in different crops [60], there are also examples of identical phenotypes caused by different unrelated genes [68]. Not surprisingly, flowering time is controlled by a set of highly conserved genes across distinct plant families (e.g., [69]) but also by mutations in genes that are nonhomologous but that occupy analogous network positions within the floral induction pathway. For example, FLC and VRN2, which are both repressors of flowering and become downregulated by vernalization [70].

A distinction can be made between true convergence, in which analogous states have been reached from very different and unrelated starting points, versus parallelism, in which similar pathways of change follow from similar starting points, for example, as with taxa that share the same underlying developmental ontogeny and orthologous genetic loci [71].

All of these processes led to the suite of so-called domestication syndrome traits [72]; that is, traits can arise through human preferences to facilitate harvest, growth advantages under human propagation, and / or survival in deforested or disturbed habitats. These traits include reduced dispersal ability of seeds and fruits, changes to plant structure, changes to plant defensive characteristics, changes in plant phenology (crop wild relatives (CWR) may be perennial or biannual, while many crops are annual with a profound tendency towards earliness [73]), and palatability [68]. Domestication 
syndrome differs for various crop plants according primarily to how they are reproduced (by seed or by cuttings) and according to which plant organ is the target of selection.

The best-defined and studied domestication syndrome is for grain crops, including cereals, pulses, and oilseeds [71]. These include loss of germination inhibition, increase of seed size, linked to successful early growth of planted seeds, and the loss of natural seed dispersal [43]. The loss of fruit shattering has been under selection in most seed crops, while in wild plants, shattering is assumed to be a fundamental trait to assure seed dispersal. The evolution of nonshattering could either have been under conscious or unconscious selection as a by-product of harvesting higher proportions of nonshattering variants, which were then sown at higher frequency and so on. Propensity to fruit shattering remains a problem in some crops such as rapeseed, sesame, and even landraces of rice [74], which require swathing before mechanical harvesting to reduce seeds lost to shattering $[75,76]$.

Timing of seed germination is a key step in the plant lifecycle, especially for annuals, where it defines the beginning of the growing season. In the wild, many seeds will only germinate after certain conditions have been met or after the seed coat has been physically damaged. Predictive germination that responds to cues signaling the onset of the growing season ensures that wild seeds emerge at the appropriate time, while bet-hedging germination, where cohorts of seed germinate at different times, spreads risk in time [77]. Domesticated crops are under the control of the farmer and require neither of these protective mechanisms. Accordingly, crops tend to imbibe moisture and germinate as soon as they are exposed to water, which typically drives sowing time in the farming system [78]. The selection of crops with nondormant seeds was another of the domestication syndrome traits that may have been under conscious or unconscious selection. Having a high proportion of nondormant seeds facilitates good crop establishment, and, in the case of soft-seeded legumes, reduces cooking time. Reducing seed coat thickness led to a concurrent reduction of seed coat impermeability during legume domestication [79]. Conversely, low seed dormancy levels can reduce seed viability and trigger preharvest sprouting, causing yield losses in cereals [80]. However, this is likely to be of greater concern to modern broad-acre farmers who are locked into a single, rapid, and timely harvesting process than to early agriculturalists who had the capacity to harvest their crop in a flexible manner on repeated occasions if necessary.

Domestication applies selective sweeps on standing genetic variation [81] and on new genetic variation introduced via mutation or introgression. Selection on standing genetic variation might cause the repeated involvement of the same locus in independent domestication events [33] because the selection of favorable alleles that are already present in a wild population usually proceeds faster than new mutations can arise $[68,82,83]$. On the other hand, new mutations not found in natural populations, possibly detrimental to plant survival, have been identified [39]. These include transcription factors with altered spatiotemporal expression patterns, usually with minimal pleiotropic effects [56].

Furthermore, genetic bottlenecks [43] during domestication or during founding events as crops moved away from centers of origin may have further altered genepools. Estimates of the number of loci under selection in the domestication process are wide ranging. Early experiments analyzed domestication traits as individual Mendelian (i.e., qualitative) traits [84]. In most crops, domestication syndrome is controlled by a limited number of major genes under monogenic recessive control, some of which tend to be only loosely linked (reviewed in [85]). Later on, with the availability of molecular linkage maps, it became possible to conduct quantitative analyses and estimate the magnitude of the effect and position of loci (quantitative trait loci or QTLs). To date, a few hundred genes and loci have been identified by classical genetical and association mapping as targets of domestication and postdomestication divergence [4,56,68,71]. However, only a few of these have been characterized. Many genes that underlie phenotypes which distinguish a domesticated species from its wild ancestor have been labelled as domestication genes, although in many cases, there is no evidence that these phenotypes arose as a result of selection during the domestication process [86]. Overall, most causal sequence variants in domestication or diversification genes have been found to be "nonsense mutations" or have been found to occur in regulatory regions such as the promoter, which causes 
putative cis-regulatory changes that are usually shown by altered expression $[43,67]$. Indeed, the largest proportion (43-81\%) of domestication genes identified so far are transcriptional regulators [56,68,87]. Changes at the transcriptional level during domestication have been shown in maize compared to teosinte [88] and in tomato [89]. This agrees with the idea that regulatory changes are major players in phenotypic evolution [90]. Recently, the concept of gene networks changing under domestication, leading to multiple phenotypes with different plant and inflorescence architecture, was demonstrated in maize [91]. This might not be unexpected given that transcription factors orchestrate the activity of numerous other genes, and consequently, their alteration can potentially modify an entire suite of characters, leading to drastic phenotypic changes in relatively short time scales [45,92].

\subsection{Plant Genomes: Crop Plants and Their Relatives}

Owing to rapid developments in sequencing technologies, there are now a large number of species with available genome information. By the end of 2017, 37.7\% of sequenced vascular plant species (236 angiosperm species) were crops used primarily for human food, fuel, and fiber, $17.7 \%$ were crop wild relatives, and $22.3 \%$ were noncrop models and their relatives [93].

While much is being learnt from the study of crop genomes, studying the genomes of CWR is critically important. Wild populations are much older and more diverse than domesticated crops, having undergone millennia of recombination, genetic drift, and natural selection. The contrast of wild and domestic genomes will highlight those genomic changes associated with domestication. A deeper understanding of CWR population genomics will enable us to distinguish between that diversity that has arisen as a result of demography and location as a result of isolation by distance (IBD) against that diversity which arises by selection through isolation by environment (IBE). This understanding will facilitate the introgression of adaptive diversity, rather than diversity for its own sake, providing breeders with new tools for crop improvement through drought-, insect-, and disease-resistant varieties.

The best example of this approach is Arabidopsis thaliana (Brassicaceae), the most widely studied model plant, and indeed the first species to have its whole genome sequenced in 2000 [94]. The insights gained from this genome assembly, together with ongoing studies, have established much of what is known about the molecular mechanisms underpinning plant physiology and development. It remains one of the most intensely studied plant genomes. For example, the recent release of whole genome sequences for 1135 accessions of $A$. thaliana is providing new understanding on how variation at the molecular level translates into the phenotypic variation observed in nature [95].

Comparison of wild and cultivated plants shows evidence of large-scale chromosomal structural changes [96], changes in transposable-element content and copy-number variation [97]. There is higher prevalence of recent polyploidy among major domestic crop species (34\%) than among wild plant species (24\%), with monocots exhibiting the most profound difference: $54 \%$ of the crops are recent polyploids versus $40 \%$ of the wild species [98]. Domesticated plants benefitted from the versatility of polyploids [99], such as broadening of adaptation, increase in harvested organ size (gigantism), fixation of heterozygosity, and the appearance of novel traits due to epistatic interactions. Genome duplication can serve as a postzygotic barrier reducing gene flow with wild progenitors [100].

In polyploidy, the increase in the number of genes and/or alleles can ameliorate the loss of diversity associated with the domestication bottleneck. The increase in genetic redundancy associated with multiple copy genes can act as a buffer against the accumulation of deleterious mutations and facilitate novel gene interactions [101]. In allopolyploid plants combining multiple sets of chromosomes derived from different species, there is an increased probability of accumulating different alleles and novel epistatic interactions. For example, hexaploid wheat is more broadly adapted with regard to photoperiodism and vernalization than tetraploid wheat, has improved tolerance or resistance against abiotic and biotic factors, and produces a broader range of foods [102].

In contrast to the discussion so far, some domesticated plants are clonally vegetatively propagated including both monocots (e.g., from Araceae, Dioscoreaceae, Musaceae, Poaceae, Zingiberaceae families) 
and dicots (e.g., from Euphorbiaceae, Moraceae, Oxalidaceae, Piperaceae, Solanaceae). While there are fewer recombination and selection cycles for clonal crops than for seed crops, they may be more complex in terms of parentage, breeding pattern, or interactions between scions and stocks in taxa grown with grafting [103].

Clonally propagated crops have been cultivated for various uses including food, fodder, medicine, poison, living shelter, fiber, and timber, exploiting vegetative (storage organs, stems, leaves) or floral organs (inflorescence, fruit, nut, grain). They feature many Old World domesticated fruit trees (grape, fig, sycamore fig, pomegranate, olive, date palm) that are readily vegetatively propagated by cuttings or natural offshoots. Meyer et al. [1] describes two waves of domestication in perennial crop species and links these to the dissemination of vegetative propagation techniques. The first wave concerned herbaceous perennials and trees that can be propagated simply by planting cuttings, while the second wave coincided with the discovery and dissemination of scion grafting, particularly in the Mediterranean basin. A single novel variant in an otherwise homogenous field of hand-planted clones is likely to be much more obvious to a farmer than the same situation in heterogeneous field of a seed propagated crop. In clonal crops, when a new desirable quality is discovered while preparing, cooking, or eating, the remaining part can be converted to planting stock that will preserve the new variety.

\subsection{Reduced Genetic Diversity of Crops}

The aforementioned practices of selecting favorable individuals inevitably led to a founder effect. Therefore, the domestication bottleneck and the concomitant increase in linkage disequilibrium is a widespread observation in genomic studies of annual crops [4,104]. After domestication, only favorable haplotypes are retained around selected genes, which create regions with extremely low genetic diversity. While genetic drift has a genome-wide effect in reducing genetic diversity, the reduction caused by selection is locus specific. Selection leads to selective sweeps, that is, areas of the genome that have reduced genetic diversity compared with neutrally evolving regions. These sweeps can allow mildly deleterious alleles to come to fixation by hitchhiking in linkage with strongly selected loci and may create genetic load in the cultivated gene pool [4,6,105].

Despite these bottlenecks, as crops are grown across expanded areas, their census population sizes will increase. For most broadacre crops with low outcrossing rates, this does not compensate for the loss of diversity associated with the domestication bottleneck. For example, there has been a 100-fold decrease in diversity in chickpea compared to C. reticulatum, even though the distribution of the crop is far wider than its wild progenitor [7,27]. Nevertheless, if these population expansions are accompanied by introgression events, they may introduce additional alleles into a defined population, as may occur if a compatible wild relative co-occurs in a new area [106,107]. In crops with significant introgression or hybridization (such as North African dates or citrus) and in outcrossing perennials like most tree crops [108], genetic diversity may remain high or increase in cultivated populations compared to wild relatives. Furthermore, new mutations may be important and the impact of epigenetic changes remains substantially unexplored. In many self-incompatible crops, such as many fruit trees [108], carrot (Daucus carota) [109], or scarlet runner bean (Phaseolus coccineus [110]), genetic diversity will remain high in cultivated forms and may be equivalent to wild relatives. Furthermore, the practice of grafting may preserve within-individual heterozygosity, while leading to very low stand or population level variation (e.g., [103]).

Decrease in diversity might limit the adaptation of current crops as shown in recently domesticated lupin $[50,111]$. Selective specialization in a smaller number of crops and genotypes also increases vulnerability to infestation as exemplified by black Sigatoka infestations (Mycosphaerella fijiensis) of banana plantations [112]. A canonical example of the perils of over-reliance on limited crop species and varietal diversity was the cultivation of a small number of susceptible potato varieties. This contributed to the outbreak of the Phytophthora infestans pathogen in Europe and its most devastating impact in Ireland in the mid-19th century with the Great Famine. Ironically, the Green Revolution, from the 
1960s onward, with the aid of increased irrigation, pesticides, fertilizer, and a limited number of high-yielding varieties, also contributed to the further loss of landraces from farmers' fields [113]. This has compounded more recent disease outbreaks, such as the Southern blight outbreak in maize in the late 1960s that affected most cytoplasmic male sterility (CMS) hybrid varieties then in use [114].

The decrease in diversity caused by bottlenecks and selection might be counteracted by admixture or interbreeding between domesticates and local wild populations. This process likely initially slowed domestication, and it is proposed that movement of early crops outside of centers of species origin has provided reproductive isolation resulting in better improvement of the crop. Admixture also substantially complicates the analyses of the timing and location of domestication [12].

The diversity with domesticated crop species and their wild relatives is exploited in crop production and breeding. Diversity of alleles for traits of importance in agriculture is the key to selection for genetic improvement in crops. This diversity is stored in germplasm collections worldwide. However, much of the material in seed banks remains poorly characterized, making it difficult to utilize in crop improvement.

\subsection{The Eco-Evolutionary Impacts of Domestication and Agricultural Practices}

Agriculture has replaced the majority of earth's grasslands, savannahs, and a large proportion of forests and is responsible for $30-35 \%$ of global carbon emissions, $70 \%$ of global freshwater withdrawals, and a 500\% increase in global fertilizer use over the past 50 years [115]. One of the most important drivers of rapid evolution is the homogenization of agricultural habitats and the high density of domesticated species in order to maximize production. Agricultural practices have been used for millennia and have generated strong selection both on crops as well as wild organisms. For instance, weed species have evolved to morphologically mimic crops and, in this way, evade eradication by practices such as hand-weeding or seed sorting and cleaning [116]. Similarly, despite limited study, it is clear that crop domestication has had large impacts on herbivorous insect communities and on natural enemies of herbivores, such as parasitoids [117]. Evolution of wild species in response to agricultural practices can both directly and indirectly impact the provision of multiple ecosystem services, such as rapid evolution in pests, pathogens, and weeds causing stark declines in crop production [118].

\subsection{Ecophysiological and Nutritional Aspects}

Ecophysiological studies of annual CWR across their distribution ranges demonstrate how adaptive strategies vary across stress gradients. Typically, phenology becomes earlier as habitats become more disturbed or stressful, reducing biomass accumulation (e.g., leaf area, root weight) and yield potential but increasing reproductive investment (harvest index) [73,111,119]. Conversely, in higher rainfall, longer season environments, phenology is delayed, increasing leaf area, root weight, and productivity while reducing reproductive investment. These different attributes have flow-on effects on water-use and stress onset under terminal drought [111]. These trade-offs follow Grime's predictions [120] that short season habitats "disturbed" by terminal drought will select for ruderal escape strategies, while higher rainfall, longer season habitats will select for more competitive strategies emphasizing resource acquisition - the tension between stress escape and maximizing yield potential. Among widespread Mediterranean lupin species, there is a further seed size-phenology trade-off, where seed size and flowering time are negatively correlated [73], which follows another dimension of known trade-offs in plant functional strategies [121]. Large seeds in early, drought escaping germplasm are likely to increase early vigor, facilitating an early completion of the lifecycle. Conversely, small seeds in late flowering material may be a bet hedging strategy to facilitate seed fill in a relatively short reproductive phase [73].

By definition, domesticated crops are unlikely to have sampled the range of wild adaptive strategies during domestication, particularly in widespread species such as the Old World lupins or South and East Asian Vigna species. This constrains their adaptive potential, limiting where the crop can be grown. This is the case even when adaptive strategies are defined only by phenology and seed 
size. For example, there are no narrow-leafed lupin cultivars for long-season environments because the only current domestic option for later flowering is to reintroduce the vernalization response, which is an unreliable regulator of flowering in the area where $>75 \%$ of the world crop is grown $[49,50]$. In lupin, a key research focus is the identification of alternative flowering alleles that will moderately delay flowering in warm environments. Lupin CWR have much to offer here, with very promising material with unique FLOWERING LOCUS T (FT) regulation identified in eastern Mediterranean germplasm [122]. As CWR adaptive strategies become more complex, there is even less likelihood of their having passed through the domestication bottleneck. For example, under low water stress, high-rainfall yellow lupin ecotypes can maintain leaf relative water content at lower critical leaf water potential, a tolerance capacity that is lacking from both low rainfall ecotypes and domesticated yellow lupin [111]. The lesson for domestication and crop improvement is that CWR adaptive strategies must be well understood, using well-characterized, widely distributed germplasm in order to properly describe the adaptive potential of the species as a whole.

The same argument applies to crop nutrient content. Although the population genomic consequences of domestication give several predictions for levels of the genetic diversity in crops, our understanding of how this diversity corresponds to nutritional aspects of crops is not well understood. Many studies have found that modern cultivars have lower levels of key micronutrients such as iron, zinc, and vitamins [123-125]. These declines have been partially attributed to climate change [126], agricultural practices that have reduced soil fertility, modern breeding for yield [125,127-129], and potentially to trade-offs between harvest index and total biomass, or similar trade-offs among parts of harvested plant organs. In many CWR, wild relatives can be found to contain higher levels of nutrients as well as greater levels of antinutritional compounds such as phytic acid [129]. We suspect that selection for palatability and increased yield at domestication and during postdomestication divergence exacerbated the low nutrient levels of many crops, although relatively little work has examined this question. Lack of diversity in modern germplasm may further limit our capacity to breed for higher nutrient levels, although little effort has gone into this beyond a handful of staple crops. This is an area where an understanding of domestication across many crop taxa may provide the necessary insight to breed more nutritious crops in a rapidly changing world. Furthermore, maintaining a diversity of species in human diets is likely essential to sustainable improvement in human nutrition.

A key part of understanding how nutrients in the soil interact with crop genotypes to provide nutrient dense food is an improved understanding of the soil microbial communities that are essential to mobilizing many nutrients. There is growing evidence that microbial partnerships can alter plant nutrient status beyond simply levels of nitrogen or phosphorus (e.g., [130,131]). In recent years, our capacity to characterize the microbiome of plants has increased immensely (e.g., [125,132]) with enormous potential for agriculture and plant biology. We have learned that roots have a major effect on structuring the soil microbial community, with suites of taxa most commonly enriched near plant roots [133]. The ecological roles of most soil microbes remain very poorly known, although some are expected to perform a range of beneficial functions from mobilizing recalcitrant nutrients such as phosphorus and iron under higher soil pH or protecting against pathogenic microbes (e.g., [134]). Although there are effects of plant species and genotype identity, the role of plant $\mathrm{R}$ genes or root exudates in structuring root microbiomes are not yet well known. Furthermore, we know very little about how domestication impacted microbial communities (but see [135-137]). Early agriculture must have caused significant impacts on soil microbial communities, from clearing land and altering plant communities, to tilling and disturbing soil, to changing soil fertility [138]. We suspect that changes in microbiomes during domestication may have had enormous impacts on symbiotic relationships as well as crop relations with pathogens, although evidence for this is quite limited to date. This is an area where we expect exciting research to emerge in the coming years. 


\section{The Future of Crop Domestication}

Increasing demands for high-quality food from a growing, increasingly affluent global population coupled with climate change and a shrinking resource base (arable land, N, P, etc.) create the perfect storm for society, where agriculture is being asked to produce more from less. To meet this challenge, agriculture must deploy all the tools at its disposal. In the context of crop improvement, this means identifying and exploiting all the useful genetic diversity available in our crop genepools (e.g., introgression/redomestication from CWR), as well as widening our vision to domesticate new crops.

\subsection{Use of Crop Wild Relatives-Introgression}

CWR represent the largest reservoir of genetic diversity for crop improvement. Despite their potential, CWR are underutilized in breeding programs (e.g., [139-141]) and underrepresented in international gene banks (e.g., [141,142]). Breeders are often nervous about diluting elite domestic genepools with wild traits. Accordingly, CWR have typically been deployed in breeding to introgress a small number of major genes, for example, for disease and pest resistance $[139,140,143]$ or CMS, such as in maize, sunflower, and pigeon pea $[144,145]$. Major genes are relatively easy to identify in biparental populations and then implement in breeding.

However, many agriculturally significant traits such as yield, quality, and adaptation are controlled by many genes, and so more sophisticated population development approaches are required to identify these and implement them in breeding. Notable examples are provided in rice [146], wheat [147], maize [148], tomato [149], and narrow-leafed lupin [5]. These approaches can be further improved by careful selection of founder CWR parent accessions, using passport data describing their ecological and evolutionary context so that locally adaptive traits can be introgressed into the crop [47]. For example, wild parents from different soil types or climates $[7,73]$ may be intentionally selected to provide adaptation to particular conditions. When larger collections are established on ecological and population genetic principles to capture as much representative variation as possible, whole genome sequencing can be deployed to develop purpose-built large-scale introgression populations [47]. Advanced backcross introgression populations, with some of the characteristics of Nested Association Mapping populations [150], can be ideal for both mapping domestication and agronomic traits and for transferring adaptive traits controlled by one or many genes into cultivated backgrounds [151].

Beyond the need for greatly expanded collections built on ecological principles, for which we have advocated frequently (e.g., $[7,26,27,47,50,152-154]$ ), there is a growing need is to develop the means to harness wild material in genome-enabled breeding programs. Although the rapidly declining cost of sequencing makes genome-wide characterization of most crops increasingly feasible, even in species like lentil with large and complex genomes (e.g., [155]), sequencing alone is not enough to predict useful phenotypes. Genomic prediction and selection, which has become increasingly powerful in crops ranging from staples like maize and rice to chickpea [156-160], is usually built on training populations composed of elite varieties. An underappreciated challenge is that as new diversity is brought into breeding populations, prediction models will need to be reconstructed every cycle, increasing phenotypic and computational burdens and costs. Utilizing information from advanced backcross population development when adding CWR diversity to genomic selection may help reduce this burden, allowing improved prediction of the performance of wild alleles in elite cultivated genetic backgrounds.

\subsection{Domestication of Wild or Semiwild Plant Species}

An estimated 2500 plant species have been domesticated to varying levels of completeness [161], ranging from primarily wild-harvested species such as Brazil nut (Bertholletia excelsa Humb. \& Bonpl.) to highly developed field crops such as wheat. Some species lend themselves to cultivation more readily than others. Large-seeded, self-pollinated, annual grasses that grow well in monocultural 
swards such as wheat are ideally suited to cultivation by humans. In contrast, Brazil nut offers a much greater challenge for domestication owing to the large size of the plant (up to $50 \mathrm{~m}$ in height), long life cycle (trees may live for over 400 years), and its highly specific cross-pollination requirements [162]. However, even in such extreme cases, there may be scope for achieving domestication using such approaches as grafting onto dwarfing rootstocks and developing self-pollinating types, as has been achieved in other fruit and nut tree species. Perennial grain legumes have been particularly neglected in the past century of agricultural development $[163,164]$. Given our increasing reliance on fewer and fewer crop species, and the need to more sustainably intensify agricultural production and to develop more nutritious crops, completing their domestication is an urgent priority. While conventional breeding by hybridization and progeny selection augmented by marker-assisted selection are likely to be the most practicable approaches for the time-being, recent developments in genome-editing technologies may help accelerate this process in future by converting key domestication genes from the wild to domesticated forms [165]. This, of course, requires knowledge of the genes underlying domestication traits, which is increasing thanks to rapidly evolving genome sequencing technologies.

The African continent provides two insightful examples of legume species meriting full domestication: the marama bean (Tylosema esculentum (Burchell) A. Schreiber) and the African locust bean (Parkia biglobosa (Jacq.) R.Br. ex G.Don) (Figure 1).

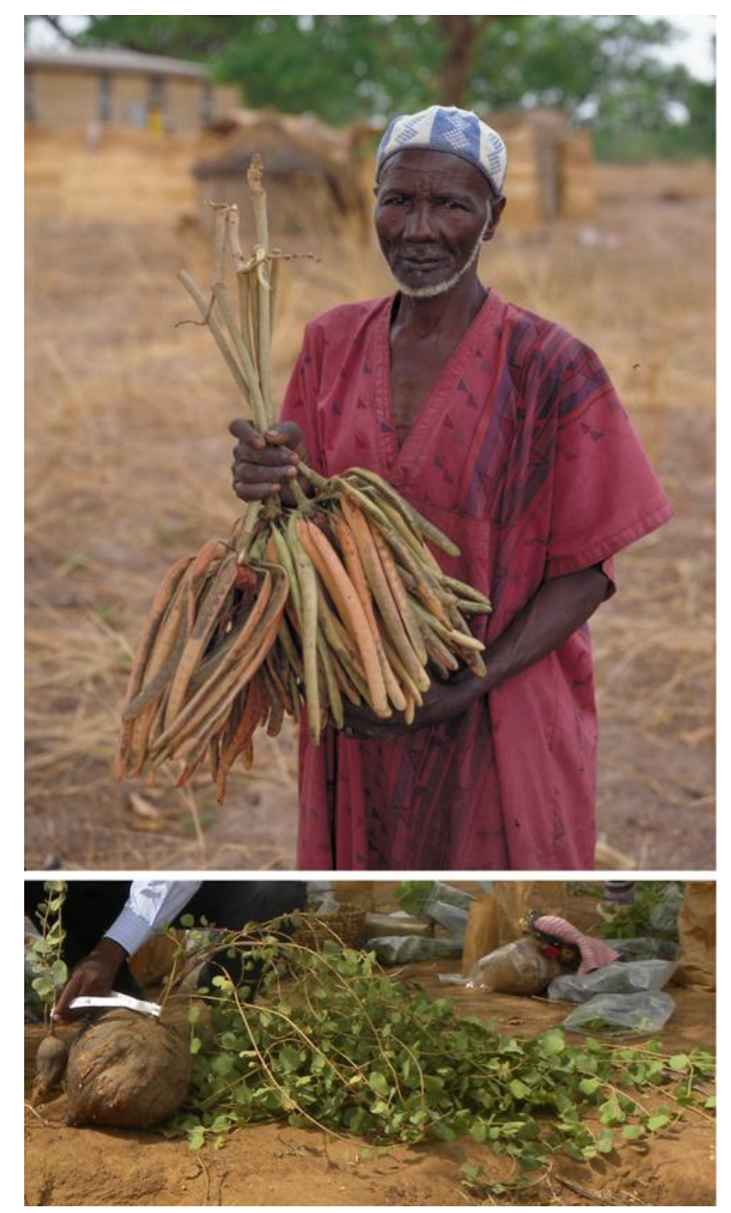

Figure 1. Two African legume species that are predominantly wild-harvested and merit full domestication. The upper panel shows a village elder in Burkina Faso holding Parkia biglobosa pods. The highly nutritious seeds and pod pulp are used in a range of traditional foods and medicines (photo by Andy McRobb, Royal Botanic Gardens, Kew). The lower panel shows two contrasting genotypes of Tylosema esculentum in the experimental fields of the Botswana University of Agriculture and Natural Resources in Gaborone, Botswana (photo by Efisio Mattana, Royal Botanic Gardens, Kew). 


\subsection{Marama Bean}

The legume genus Tylosema (Tribe: Cercideae) comprises five species endemic to the arid and semiarid regions of Sub-Saharan Africa [166,167]. All are long-lived perennials with large tubers that allow the plants to survive prolonged periods of drought and to respond rapidly to rainfall events by producing long (3-6 $\mathrm{m}$ ) vines which flower profusely and produce large nuts. The species most regularly used by people is the marama bean (T. esculentum), which is distributed across arid and semiarid parts of Botswana, Namibia, and South Africa (Figure 1). It has been used as a wild-harvested staple food and source of traditional medicines for centuries by indigenous peoples of the Kalahari [168]. While all parts of the plant are used, the seeds and tubers are most prized. The large (2-3 g) seeds are high in protein $(29-39 \%)$, oil (24-48\%), and a range of B vitamins and minerals. When roasted, the seeds have a pleasant taste resembling cashew nuts. Seeds are also used to produce milk, oil, and flour, while the tubers, which can grow up to $200 \mathrm{~kg}$ in size, are used as sources of carbohydrate, protein, and water [168]. Extracts from this species are commonly used to treat inflammatory disorders, viruses, and skin diseases $[169,170]$.

Tylosema species are still exclusively wild-harvested but have great potential in cultivation as a combined cash crop and food security crop. In good seasons, high-quality seeds are produced that can either be consumed locally or sold as a cash crop; in low-rainfall seasons, the large tubers can be used as emergency food sources. Marama bean (T. esculentum) was first discussed as a target for domestication 35 years ago [171], but still this has not yet been achieved. We believe a coordinated effort drawing on expertise across the Kalahari region and international partners could achieve this goal. The same approach could also be used with T. fassoglense, which is more widely distributed across sub-Saharan Africa.

\subsection{African Locust Bean}

African locust bean (Parkia biglobosa, also known as néré) is an ecologically and economically important legume tree species distributed from Senegal to Uganda [172]. All parts of the tree are used as a source of food, medicine, and fuel. The seeds and pulp from the fruits are highly nutritious and used extensively in traditional cuisines (Figure 1). However, over-exploitation combined with increased desertification is leading to its decline across West Africa. Urgent action is required to halt and reverse this sinister trend.

While human selection has influenced wild stands of African locust bean, this species has never been fully domesticated. Domestication offers many advantages: (1) trees may be selected for the best productivity traits (e.g., high seed production), reduced height (to facilitate harvesting), high levels of bioactive compounds, and a wide range of phenology (to provide fruits all year around); (2) crossing and selection can combine these traits in new and useful combinations; and (3) reduced reliance on wild-harvesting, halting the decline in wild tree diversity.

Rapid advances in genomic technologies will facilitate the domestication of species such as marama bean and African locust bean [173]. Both species have been targeted for genome sequencing in the African Orphan Crops Consortium (http:/ / africanorphancrops.org/). Availability of reference genome sequences will aid basic research into the control of key life cycle and productivity traits and the development of molecular marker tools for marker-assisted selection in domestication and breeding programs.

\section{Concluding Remarks}

Although we work at a time when we have powerful new tools to dissect plant genomes and to identify microbial partners of plants, we also work at a time of great challenges for the conservation of natural areas and the flora and fauna that call them home [142,174]. Despite a growing number of efforts [142,174,175], most crop wild relatives are poorly represented in ex situ germplasm collections and rarely if ever receive formal protection in the wild $[142,176]$. This lack of protection hinders their 
use and their long-term value to breeding efforts and to the food security of humanity and must remain one of our leading conservation priorities. To protect our staple crops and to develop other crops, we must preserve the genetic potential needed to aid in the adaptation of crops to a rapidly evolving growth environment.

Author Contributions: P.S., M.N.N., J.D.B. and E.J.B.v.W. wrote the manuscript.

Funding: This research was funded by Vermont State Agricultural Experimental Station, grant number (US NSF-PGRP 1339346) and by Russian Scientific Fund, grant number (18-46-08001) to EvW. PS research was funded by the Grant Agency of the Czech Republic, grant number (16-21053S) and Palacky University Grant Agency, grant number (IGA 2018_001). JB research was funded by the CSIRO and the Grains Research and Development Corporation (GRDC).

Acknowledgments: We thank Chris Krieg for helpful comments and Emily Warschefsky for useful discussion.

Conflicts of Interest: The authors declare no conflicts of interest.

\section{References}

1. Meyer, R.S.; DuVal, A.E.; Jensen, H.R. Patterns and processes in crop domestication: An historical review and quantitative analysis of 203 global food crops. New Phytol. 2012, 196, 29-48. [CrossRef] [PubMed]

2. Diamond, J. Collapse: How Societies Choose to Fail or Succeed; Penguin: London, UK, 2005.

3. Gross, B.L.; Olsen, K.M. Genetic perspectives on crop domestication. Trends Plant. Sci. 2010, 15, 529-537. [CrossRef] [PubMed]

4. Olsen, K.M.; Wendel, J.F. A Bountiful Harvest: Genomic Insights into Crop Domestication Phenotypes. Annu. Rev. Plant. Biol. 2013, 64, 47-70. [CrossRef] [PubMed]

5. Cowling, W.A.; Buirchell, B.J.; Falk, D.E. A model for incorporating novel alleles from the primary gene pool into elite crop breeding programs while reselecting major genes for domestication or adaptation. Crop Pasture Sci. 2009, 60, 1009-1015. [CrossRef]

6. Varshney, R.K.; Saxena, R.K.; Upadhyaya, H.D.; Khan, A.W.; Yu, Y.; Kim, C.; Rathore, A.; Kim, D.; Kim, J.; An, S.; et al. Whole-genome resequencing of 292 pigeonpea accessions identifies genomic regions associated with domestication and agronomic traits. Nat. Genet. 2017, 49, 1082-1088. [CrossRef] [PubMed]

7. Von Wettberg, E.J.B.; Chang, P.L.; Başdemir, F.; Carrasquila-Garcia, N.; Korbu, L.B.; Moenga, S.M.; Bedada, G.; Greenlon, A.; Moriuchi, K.S.; Singh, V.; et al. Ecology and genomics of an important crop wild relative as a prelude to agricultural innovation. Nat. Commun. 2018, 9, 649. [CrossRef] [PubMed]

8. Report, K. The State of the World's Plants Report 2017; Kew Gardens: London, UK, 2017.

9. Pimm, S.L.; Joppa, L.N. How Many Plant Species are There, Where are They, and at What Rate are They Going Extinct? Ann. Mo. Bot. Gard. 2015, 100, 170-176. [CrossRef]

10. Chase, M.W.; Christenhusz, M.J.M.; Fay, M.F.; Byng, J.W.; Judd, W.S.; Soltis, D.E.; Mabberley, D.J.; Sennikov, A.N.; Soltis, P.S.; Stevens, P.F. An update of the Angiosperm Phylogeny Group classification for the orders and families of flowering plants: APG IV. Bot. J. Linn. Soc. 2016, 181, 1-20.

11. Khoury, C.K.; Bjorkman, A.D.; Dempewolf, H.; Ramirez-Villegas, J.; Guarino, L.; Jarvis, A.; Rieseberg, L.H.; Struik, P.C. Increasing homogeneity in global food supplies and the implications for food security. Proc. Natl. Acad. Sci. USA 2014, 111, 4001-4006. [CrossRef] [PubMed]

12. Larson, G.; Piperno, D.R.; Allaby, R.G.; Purugganan, M.D.; Andersson, L.; Arroyo-Kalin, M.; Barton, L.; Climer Vigueira, C.; Denham, T.; Dobney, K.; et al. Current perspectives and the future of domestication studies. Proc. Natl. Acad. Sci. USA 2014, 111, 6139-6146. [CrossRef] [PubMed]

13. Pollan, M. The Omnivore's Dilemma: A Natural History of Four Meals; Penguin: New York, NY, USA, 2006.

14. Levitin, D.J. The Organized Mind: Thinking Straight in the Age of Information Overload; Dutton Penguin Random House: New York, NY, USA, 2014.

15. FAO. FAOSTAT; Food and Agriculture Organization of the United Nations: Rome, Italy, 2015; Volume 2015.

16. De Candolle, A. Origin of Cultivated Plants; American Association for the Advancement of Science: Appleton, WI, USA, 1890.

17. Vavilov, N.I. Origin and Geography of Cultivated Plants; Cambridge University Press: Cambridge, UK, 1926.

18. Harlan, J.R.; de Wet, J.M.J. Toward a Rational Classification of Cultivated Plants. Taxon 1971, 20, 509-517. [CrossRef] 
19. Gaut, B.S.; Wright, S.I.; Rizzon, C.; Dvorak, J.; Anderson, L.K. Recombination: An underappreciated factor in the evolution of plant genomes. Nat. Rev. Genet. 2007, 8, 77-84. [CrossRef] [PubMed]

20. Abbo, S.; Gopher, A. Near Eastern Plant Domestication: A History of Thought. Trends Plant Sci. 2017, 22, 491-511. [CrossRef] [PubMed]

21. Lev-Yadun, S.; Gopher, A.; Abbo, S. The cradle of agriculture. Science 2000, 288, 1602-1603. [CrossRef] [PubMed]

22. Abbo, S.; Lev-Yadun, S.; Gopher, A. Agricultural Origins: Centers and Noncenters: A Near Eastern Reappraisal. Crit. Rev. Plant Sci. 2010, 29, 317-328. [CrossRef]

23. Civáň, P.; Ivaničová, Z.; Brown, T.A. Reticulated Origin of Domesticated Emmer Wheat Supports a Dynamic Model for the Emergence of Agriculture in the Fertile Crescent. PLoS ONE 2013, 8, e81955. [CrossRef] [PubMed]

24. Fuller, D.Q.; Willcox, G.; Allaby, R.G. Cultivation and domestication had multiple origins: Arguments against the core area hypothesis for the origins of agriculture in the Near East. World Archaeol. 2011, 43, 628-652. [CrossRef]

25. Fuller, D.Q.; Willcox, G.; Allaby, R.G. Early agricultural pathways: Moving outside the 'core area' hypothesis in Southwest Asia. J. Exp. Bot. 2012, 63, 617-633. [CrossRef] [PubMed]

26. Berger, J.; Abbo, S.; Turner, N.C. Ecogeography of annual wild Cicer species: The poor state of the world collection. Crop Sci. 2003, 43, 1076-1090. [CrossRef]

27. Abbo, S.; Berger, J.; Turner, N.C. Evolution of cultivated chickpea: Four bottlenecks limit diversity and constrain adaptation. Funct. Plant Biol. 2003, 30, 1081-1087. [CrossRef]

28. Pankin, A.; Altmüller, J.; Becker, C.; Korff, M. Targeted resequencing reveals genomic signatures of barley domestication. New Phytol. 2018, 218, 1247-1259. [CrossRef] [PubMed]

29. Poets, A.M.; Fang, Z.; Clegg, M.T.; Morrell, P.L. Barley landraces are characterized by geographically heterogeneous genomic origins. Genome Biol. 2015, 16, 173. [CrossRef] [PubMed]

30. Cornille, A.; Giraud, T.; Smulders, M.J.M.; Roldán-Ruiz, I.; Gladieux, P. The domestication and evolutionary ecology of apples. Trends Genet. 2014, 30, 57-65. [CrossRef] [PubMed]

31. Civán̆, P.; Craig, H.; Cox, C.J.; Brown, T.A. Three geographically separate domestications of Asian rice. Nat. Plant. 2015, 1, 15164. [CrossRef] [PubMed]

32. Choi, J.Y.; Platts, A.E.; Fuller, D.Q.; Hsing, Y.-I.; Wing, R.A.; Purugganan, M.D. The Rice Paradox: Multiple Origins but Single Domestication in Asian Rice. Mol. Biol. Evol. 2017, 34, 969-979. [CrossRef] [PubMed]

33. Civáň, P.; Brown, A.T. Origin of rice (Oryza sativa L.) domestication genes. Genet. Resour. Crop Evolut. 2017, 64, 1125-1132. [CrossRef] [PubMed]

34. Allaby, R.G.; Fuller, D.Q.; Brown, T.A. The genetic expectations of a protracted model for the origins of domesticated crops. Proc. Natl. Acad. Sci. USA 2008, 105, 13982-13986. [CrossRef] [PubMed]

35. Gao, L.-Z.; Innan, H. Nonindependent Domestication of the Two Rice Subspecies, Oryza sativa ssp. indica and ssp. japonica, Demonstrated by Multilocus Microsatellites. Genetics 2008, 179, 965-976. [PubMed]

36. Hillman, G.C.; Davies, M.S. 6. Domestication rates in wild-type wheats and barley under primitive cultivation. Biol. J. Linn. Soc. 1990, 39, 39-78. [CrossRef]

37. Zohary, D. Unconscious Selection and the Evolution of Domesticated Plants. Econ. Bot. 2004, 58, 5-10. [CrossRef]

38. Darwin, C. On the Origin of Species; Murray: London, UK, 1859.

39. Hancock, J.F. Plant Evolution and the Origin of Crop Species; CABI: Wallingford, UK, 2012.

40. Piperno, D.R. Assessing elements of an extended evolutionary synthesis for plant domestication and agricultural origin research. Proc. Natl. Acad. Sci. USA 2017, 114, 6429-6437. [CrossRef] [PubMed]

41. Berger, J.D.; Milroy, S.P.; Turner, N.C.; Siddique, K.H.M.; Imtiaz, M.; Malhotra, R. Chickpea evolution has selected for contrasting phenological mechanisms among different habitats. Euphytica 2011, 180, 1-15. [CrossRef]

42. Abbo, S.; Pinhasi van-Oss, R.; Gopher, A.; Saranga, Y.; Ofner, I.; Peleg, Z. Plant domestication versus crop evolution: A conceptual framework for cereals and grain legumes. Trends Plant Sci. 2014, 19, 351-360. [CrossRef] [PubMed]

43. Purugganan, M.D.; Fuller, D.Q. The nature of selection during plant domestication. Nature 2009, 457, $843-848$. [CrossRef] [PubMed]

44. Harlan, J.R. Crops and Man; American Society of Agronomy: Madison, WI, USA, 1992. 
45. Kantar, M.B.; Nashoba, A.R.; Anderson, J.E.; Blackman, B.K.; Rieseberg, L.H. The Genetics and Genomics of Plant Domestication. Bioscience 2017, 67, 971-982. [CrossRef]

46. Piperno, D.R.; Holst, I.; Winter, K.; McMillan, O. Teosinte before domestication: Experimental study of growth and phenotypic variability in Late Pleistocene and early Holocene environments. Quat. Int. 2015, 363, 65-77. [CrossRef]

47. Warschefsky, E.; Varma, P.R.; Cook, D.R.; von Wettberg, E.J. Back to the wilds: Tapping evolutionary adaptations for resilient crops through systematic hybridization with crop wild relatives. Am. J. Bot. 2014, 101, 1791-1800. [CrossRef] [PubMed]

48. Dempewolf, H.; Hodgins, K.A.; Rummell, S.E.; Ellstrand, N.C.; Rieseberg, L.H. Reproductive Isolation during Domestication. Plant Cell 2012, 24, 2710-2717. [CrossRef] [PubMed]

49. Berger, J.D.; Buirchell, B.; Luckett, D.J.; Palta, J.A.; Ludwig, C.; Liu, D. How has narrow-leafed lupin changed in its 1st 40 years as an industrial, broad-acre crop? A GxE-based characterization of yield-related traits in Australian cultivars. Field Crops Res. 2012, 126, 152-164. [CrossRef]

50. Berger, J.D.; Buirchell, B.; Luckett, D.J.; Nelson, M.N. Domestication bottlenecks limit genetic diversity and constrain adaptation in narrow-leafed lupin (Lupinus angustifolius L.). Theor. Appl. Genet. 2012, 124, 637-652. [CrossRef] [PubMed]

51. Gladstones, J.S. An historical review of lupins in Australia. In Proceedings of the 1st Lupin Technical Symposium, Perth, WA, USA, 17-21 October 1994; pp. 1-38.

52. Dixit, G.P.; Parihar, A.K.; Bohra, A.; Singh, N.P. Achievements and prospects of grass pea (Lathyrus sativus L.) improvement for sustainable food production. Crop J. 2016, 4, 407-416. [CrossRef]

53. Hillocks, R.; Gowda, M. Grass pea (Lathyrus sativus): Is there a case for further crop improvement? Euphytica 2012, 186, 647-654. [CrossRef]

54. Knights, E.J.; Southwell, R.J.; Schwinghamer, M.W.; Harden, S. Resistance to Phytophthora medicaginis Hansen and Maxwell in wild Cicer species and its use in breeding root rot resistant chickpea (Cicer arietinum L.). Aust. J. Agric. Res. 2008, 59, 383-387. [CrossRef]

55. Thompson, J.N.; Reen, R.A.; Clewett, T.G.; Sheedy, J.G.; Kelly, A.M.; Gogel, B.J.; Knights, E.J. Hybridisation of Australian chickpea cultivars with wild Cicer spp. increases resistance to root-lesion nematodes (Pratylenchus thornei and P. neglectus). Australas. Plant Pathol. 2011, 40, 601-611. [CrossRef]

56. Lenser, T.; Theißen, G. Molecular mechanisms involved in convergent crop domestication. Trends Plant Sci. 2013, 18, 704-714. [CrossRef] [PubMed]

57. Vavilov, N.I. The law of homologous series in variation. J. Genet. 1922, 12, 47-89. [CrossRef]

58. Cheng, F.; Sun, R.; Hou, X.; Zheng, H.; Zhang, F.; Zhang, Y.; Liu, B.; Liang, J.; Zhuang, M.; Liu, Y.; et al. Subgenome parallel selection is associated with morphotype diversification and convergent crop domestication in Brassica rapa and Brassica oleracea. Nat. Genet. 2016, 48, 1218-1224. [CrossRef] [PubMed]

59. Martin, A.; Orgogozo, V. The loci of repeated evolution: A catalog of genetic hotspots of phenotypic variation. Evolution 2013, 67, 1235-1250. [CrossRef] [PubMed]

60. Lin, Z.; Li, X.; Shannon, L.M.; Yeh, C.-T.; Wang, M.L.; Bai, G.; Peng, Z.; Li, J.; Trick, H.N.; Clemente, T.E.; et al. Parallel domestication of the Shattering1 genes in cereals. Nat. Genet. 2012, 44, 720-724. [CrossRef] [PubMed]

61. Katkout, M.; Sakuma, S.; Kawaura, K.; Ogihara, Y. TaqSH1-D, wheat ortholog of rice seed shattering gene qSH1, maps to the interval of a rachis fragility QTL on chromosome 3DL of common wheat (Triticum aestivum). Genet. Resour. Crop Evol. 2015, 62, 979-984. [CrossRef]

62. Repinski, S.L.; Kwak, M.; Gepts, P. The common bean growth habit gene PvTFL1y is a functional homolog of Arabidopsis TFL1. Theor. Appl. Genet. 2012, 124, 1539-1547. [CrossRef] [PubMed]

63. Mir, R.R.; Kudapa, H.; Srikanth, S.; Saxena, R.K.; Sharma, A.; Azam, S.; Saxena, K.; Varma Penmetsa, R.; Varshney, R.K. Candidate gene analysis for determinacy in pigeonpea (Cajanus spp.). Theor. Appl. Genet. 2014, 127, 2663-2678. [CrossRef] [PubMed]

64. Blackman, B.K.; Strasburg, J.L.; Raduski, A.R.; Michaels, S.D.; Rieseberg, L.H. The Role of Recently Derived FT Paralogs in Sunflower Domestication. Curr. Biol. 2010, 20, 629-635. [CrossRef] [PubMed]

65. Zhou, L.; Wang, S.-B.; Jian, J.; Geng, Q.-C.; Wen, J.; Song, Q.; Wu, Z.; Li, G.-J.; Liu, Y.-Q.; Dunwell, J.M.; et al. Identification of domestication-related loci associated with flowering time and seed size in soybean with the RAD-seq genotyping method. Sci. Rep. 2015, 5, 9350. [CrossRef] [PubMed]

66. Tsuji, H.; Taoka, K.-I.; Shimamoto, K. Regulation of flowering in rice: Two florigen genes, a complex gene network, and natural variation. Curr. Opin. Plant Biol. 2011, 14, 45-52. [CrossRef] [PubMed] 
67. Nelson, M.N.; Książkiewicz, M.; Rychel, S.; Besharat, N.; Taylor, C.; Wyrwa, K.; Jost, R.; Erskine, W.; Berger, J.; Batley, J.; et al. A $1.4 \mathrm{~kb}$ deletion in the regulatory region of a Flowering Locus T homologue is associated with the loss of vernalisation responsiveness in Lupinus angustifolius L. New Phytol. 2017, 213, 220-232. [CrossRef] [PubMed]

68. Meyer, R.S.; Purugganan, M.D. Evolution of crop species: Genetics of domestication and diversification. Nat. Rev. Genet. 2013, 14, 840-852. [CrossRef] [PubMed]

69. Weller, J.L.; Ortega, R. Genetic control of flowering time in legumes. Front. Plant Sci. 2015, 6, 207. [CrossRef] [PubMed]

70. Alonso-Blanco, C.; Aarts, M.G.M.; Bentsink, L.; Keurentjes, J.J.B.; Reymond, M.; Vreugdenhil, D.; Koornneef, M. What Has Natural Variation Taught Us about Plant Development, Physiology, and Adaptation? Plant Cell 2009, 21, 1877-1896. [CrossRef] [PubMed]

71. Fuller, D.Q.; Allaby, R. Seed Dispersal and Crop Domestication: Shattering, Germination and Seasonality in Evolution under Cultivation. In Annual Plant Reviews: Fruit Development and Seed Dispersal; Østergaard, L., Ed.; John Wiley \& Sons: Hoboken, NJ, USA, 2009; Volume 38.

72. Hammer, K. Das Domestikationssyndrom. Die Kulturpflanze 1984, 32, 11-34. [CrossRef]

73. Berger, J.D.; Shrestha, D.; Ludwig, C. Reproductive Strategies in Mediterranean Legumes: Trade-Offs between Phenology, Seed Size and Vigor within and between Wild and Domesticated Lupinus Species Collected along Aridity Gradients. Front. Plant Sci. 2017, 8, 548. [CrossRef] [PubMed]

74. Ray, A.; Chakraborty, D. Shattering or not shattering: That is the question in domestication of rice (Oryza sativa L.). Genet. Resour. Crop Evol. 2018, 65, 391-395. [CrossRef]

75. Moazzami, A.A.; Kamal-Eldin, A. Sesame seed is a rich source of dietary lignans. J. Am. Oil Chem. Soc. 2006, 83, 719. [CrossRef]

76. Braatz, J.; Harloff, H.-J.; Emrani, N.; Elisha, C.; Heepe, L.; Gorb, S.N.; Jung, C. The effect of INDEHISCENT point mutations on silique shatter resistance in oilseed rape (Brassica napus). Theor. Appl. Genet. 2018, 131, 959-971. [CrossRef] [PubMed]

77. Gremer, J.R.; Kimball, S.; Venable, D.L. Within-and among-year germination in Sonoran Desert winter annuals: Bet hedging and predictive germination in a variable environment. Ecol. Lett. 2016, 19, 1209-1218. [CrossRef] [PubMed]

78. Weitbrecht, K.; Müller, K.; Leubner-Metzger, G. First off the mark: Early seed germination. J. Exp. Bot. 2011, 62, 3289-3309. [CrossRef] [PubMed]

79. Smýkal, P.; Vernoud, V.; Blair, M.W.; Soukup, A.; Thompson, R.D. The role of the testa during development and in establishment of dormancy of the legume seed. Front. Plant Sci. 2014, 5, 351. [PubMed]

80. Liu, S.; Sehgal, S.K.; Li, J.; Lin, M.; Trick, H.N.; Yu, J.; Gill, B.S.; Bai, G. Cloning and Characterization of a Critical Regulator for Preharvest Sprouting in Wheat. Genetics 2013, 195, 263-273. [CrossRef] [PubMed]

81. Tian, F.; Stevens, N.M.; Buckler, E.S. Tracking footprints of maize domestication and evidence for a massive selective sweep on chromosome 10. Proc. Natl. Acad. Sci. USA 2009, 106, 9979-9986. [CrossRef] [PubMed]

82. Elmer, K.R.; Meyer, A. Adaptation in the age of ecological genomics: Insights from parallelism and convergence. Trends Ecol. Evol. 2011, 26, 298-306. [CrossRef] [PubMed]

83. Tsiantis, M. A transposon in tb1 drove maize domestication. Nat. Genet. 2011, 43, 1048-1050. [CrossRef] [PubMed]

84. Ladizinsky, G. Plant Evolution under Domestication; Kluwer: Dordrecht, The Netherlands, 1998.

85. Gepts, P. Crop Domestication as a Long-Term Selection Experiment. In Plant Breeding Reviews; John Wiley \& Sons: Hoboken, NJ, USA, 2004; Volume 24, pp. 1-44.

86. Takeda, S.; Matsuoka, M. Genetic approaches to crop improvement: Responding to environmental and population changes. Nat. Rev. Genet. 2008, 9, 444-457. [CrossRef] [PubMed]

87. Martínez-Ainsworth, N.E.; Tenaillon, M.I. Superheroes and masterminds of plant domestication. C. R. Biol. 2016, 339, 268-273. [CrossRef] [PubMed]

88. Swanson-Wagner, R.; Briskine, R.; Schaefer, R.; Hufford, M.B.; Ross-Ibarra, J.; Myers, C.L.; Tiffin, P.; Springer, N.M. Reshaping of the maize transcriptome by domestication. Proc. Natl. Acad. Sci. USA 2012, 109, 11878-11883. [CrossRef] [PubMed]

89. Koenig, D.; Jiménez-Gómez, J.M.; Kimura, S.; Fulop, D.; Chitwood, D.H.; Headland, L.R.; Kumar, R.; Covington, M.F.; Devisetty, U.K.; Tat, A.V.; et al. Comparative transcriptomics reveals patterns of selection in domesticated and wild tomato. Proc. Natl. Acad. Sci. USA 2013, 110, E2655-E2662. [CrossRef] [PubMed] 
90. Carroll, S.B. Evo-Devo and an Expanding Evolutionary Synthesis: A Genetic Theory of Morphological Evolution. Cell 2008, 134, 25-36. [CrossRef] [PubMed]

91. Studer, A.J.; Wang, H.; Doebley, J.F. Selection During Maize Domestication Targeted a Gene Network Controlling Plant and Inflorescence Architecture. Genetics 2017, 207, 755-765. [CrossRef] [PubMed]

92. Stetter, M.G.; Gates, D.J.; Mei, W.; Ross-Ibarra, J. How to make a domesticate. Curr. Biol. 2017, 27, R896-R900. [CrossRef] [PubMed]

93. Chen, F.; Dong, W.; Zhang, J.; Guo, X.; Chen, J.; Wang, Z.; Lin, Z.; Tang, H.; Zhang, L. The Sequenced Angiosperm Genomes and Genome Databases. Front. Plant Sci. 2018, 9, 418. [CrossRef] [PubMed]

94. The Arabidopsis Genome, I. Analysis of the genome sequence of the flowering plant Arabidopsis thaliana. Nature 2000, 408, 796-815. [CrossRef] [PubMed]

95. Alonso-Blanco, C.; Andrade, J.; Becker, C.; Bemm, F.; Bergelson, J.; Borgwardt, K.M.; Cao, J.; Chae, E.; Dezwaan, T.M.; Ding, W.; et al. 1135 Genomes Reveal the Global Pattern of Polymorphism in Arabidopsis thaliana. Cell 2016, 166, 481-491. [CrossRef] [PubMed]

96. Yang, L.; Dal-Hoe, K.; Yuhong, L.; Xuejiao, Z.; Feishi, L.; Havey, M.J.; Jiming, J.; Yiqun, W. Chromosome rearrangements during domestication of cucumber as revealed by high-density genetic mapping and draft genome assembly. Plant J. 2012, 71, 895-906. [CrossRef] [PubMed]

97. Wang, Y.; Xiong, G.; Hu, J.; Jiang, L.; Yu, H.; Xu, J.; Fang, Y.; Zeng, L.; Xu, E.; Xu, J.; et al. Copy number variation at the GL7 locus contributes to grain size diversity in rice. Nat. Genet. 2015, 47, 944-948. [CrossRef] [PubMed]

98. Salman-Minkov, A.; Sabath, N.; Mayrose, I. Whole-genome duplication as a key factor in crop domestication. Nat. Plant 2016, 2, 16115. [CrossRef] [PubMed]

99. Renny-Byfield, S.; Wendel, J.F. Doubling down on genomes: Polyploidy and crop plants. Am. J. Bot. 2014, 101, 1711-1725. [CrossRef] [PubMed]

100. Rieseberg, L.H.; Willis, J.H. Plant Speciation. Science 2007, 317, 910-914. [CrossRef] [PubMed]

101. Gepts, P.; Papa, R. Evolution During Domestication; ELS Language Centers: Princeton, NJ, USA, 2002.

102. Dubcovsky, J.; Dvorak, J. Genome plasticity a key factor in the success of polyploid wheat under domestication. Science 2007, 316, 1862-1866. [CrossRef] [PubMed]

103. Warschefsky, E.J.; Klein, L.L.; Frank, M.H.; Chitwood, D.H.; Londo, J.P.; von Wettberg, E.J.B.; Miller, A.J. Rootstocks: Diversity, Domestication, and Impacts on Shoot Phenotypes. Trends Plant Sci. 2016, 21, 418-437. [CrossRef] [PubMed]

104. Shi, J.; Lai, J. Patterns of genomic changes with crop domestication and breeding. Curr. Opin. Plant Biol. 2015, 24, 47-53. [CrossRef] [PubMed]

105. Sedivy, E.J.; Wu, F.; Hanzawa, Y. Soybean domestication: The origin, genetic architecture and molecular bases. New Phytol. 2017, 214, 539-553. [CrossRef] [PubMed]

106. Hazzouri, K.M.; Flowers, J.M.; Visser, H.J.; Khierallah, H.S.M.; Rosas, U.; Pham, G.M.; Meyer, R.S.; Johansen, C.K.; Fresquez, Z.A.; Masmoudi, K.; et al. Whole genome re-sequencing of date palms yields insights into diversification of a fruit tree Crop. Nat. Commun. 2015, 6, 8824. [CrossRef] [PubMed]

107. Mathew, L.S.; Seidel, M.A.; George, B.; Mathew, S.; Spannagl, M.; Haberer, G.; Torres, M.F.; Al-Dous, E.K.; Al-Azwani, E.K.; Diboun, I.; et al. A Genome-Wide Survey of Date Palm Cultivars Supports Two Major Subpopulations in Phoenix dactylifera. G3 Genes Genomes Genet. 2015, 5, 1429-1438. [CrossRef] [PubMed]

108. Miller, A.J.; Gross, B.L. From forest to field: Perennial fruit crop domestication. Am. J. Bot. 2011, 98, $1389-1414$. [CrossRef] [PubMed]

109. Iorizzo, M.; Senalik, D.A.; Ellison, S.L.; Grzebelus, D.; Cavagnaro, P.F.; Allender, C.; Brunet, J.; Spooner, D.M.; Van Deynze, A.; Simon, P.W. Genetic structure and domestication of carrot (Daucus carota subsp. sativus) (Apiaceae). Am. J. Bot. 2013, 100, 930-938. [CrossRef] [PubMed]

110. Guerra-García, A.; Suárez-Atilano, M.; Mastretta-Yanes, A.; Delgado-Salinas, A.; Piñero, D. Domestication Genomics of the Open-Pollinated Scarlet Runner Bean (Phaseolus coccineus L.). Front. Plant Sci. 2017, 8, 1891. [CrossRef] [PubMed]

111. Berger, J.D.; Ludwig, C. Contrasting adaptive strategies to terminal drought stress gradients in Mediterranean legumes: Phenology, productivity and water relations in wild and domesticated Lupinus luteus L. J. Exp. Bot. 2014, 65, 6219-6229. [CrossRef] [PubMed]

112. Vezina, A. The Hidden Side of Banana Diversity. 2017, Volume 2018. Available online: http:/ /www.promusa. org/blogpost516-The-hidden-side-of-banana-diversity (accessed on 24 April 2018). 
113. Smale, M. The Green Revolution and wheat genetic diversity: Some unfounded assumptions. World Dev. 1997, 25, 1257-1269. [CrossRef]

114. Bruns, H.A. Southern Corn Leaf Blight: A Story Worth Retelling. Agron. J. 2017, 109, 1218-1224. [CrossRef]

115. Foley, J.A.; DeFries, R.; Asner, G.P.; Barford, C.; Bonan, G.; Carpenter, S.R.; Chapin, F.S.; Coe, M.T.; Daily, G.C.; Gibbs, H.K.; et al. Global Consequences of Land Use. Science 2005, 309, 570-574. [CrossRef] [PubMed]

116. Barrett, S.H. Crop mimicry in weeds. Econ. Bot. 1983, 37, 255-282. [CrossRef]

117. Chen, Y.H.; Shapiro, L.R.; Benrey, B.; Cibrián-Jaramillo, A. Back to the Origin: In Situ Studies Are Needed to Understand Selection during Crop Diversification. Front. Ecol. Evolut. 2017, 5, 125. [CrossRef]

118. Turcotte, M.M.; Araki, H.; Karp, D.S.; Poveda, K.; Whitehead, S.R. The eco-evolutionary impacts of domestication and agricultural practices on wild species. Philos. Trans. R. Soc. B Biol. Sci. 2017, 372, 20160033. [CrossRef] [PubMed]

119. Berger, J.; Palta, J.; Vadez, V. Review: An integrated framework for crop adaptation to dry environments: Responses to transient and terminal drought. Plant Sci. 2016, 253, 58-67. [CrossRef] [PubMed]

120. Grime, J.P. The C-S-R model of primary plant strategies-Origins, implications and tests. In Plant Evolutionary Biology; Gottlieb, L.D., Jain, S.K., Eds.; Springer: Dordrecht, The Netherlands, 1988; pp. 371-393.

121. Westoby, M.; Falster, D.S.; Moles, A.T.; Vesk, P.A.; Wright, I.J. Plant Ecological Strategies: Some Leading Dimensions of Variation Between Species. Annu. Rev. Ecol. Syst. 2002, 33, 125-159. [CrossRef]

122. Taylor, C.M.; Kamphuis, L.G.; Zhang, W.; Garg, G.; Berger, J.D.; Mousavi-Derazmahalleh, M.; Bayer, P.E.; Edwards, D.; Singh, K.B.; Cowling, W.A.; et al. INDEL variation in the regulatory region of the major flowering time gene LanFTc1 is associated with vernalization response and flowering time in narrow-leafed lupin (Lupinus angustifolius L.). Plant Cell Environ. 2018. [CrossRef] [PubMed]

123. Bouis, H.E.; Welch, R.M. Biofortification-A sustainable agricultural strategy for reducing micronutrient malnutrition in the global south. Crop Sci. 2010, 50, s-20-s-32. [CrossRef]

124. Diapari, M.; Sindhu, A.; Bett, K.; Deokar, A.; Warkentin, T.D.; Tar'an, B. Genetic diversity and association mapping of iron and zinc concentrations in chickpea (Cicer arietinum L.). Genome 2014, 57, 459-468. [CrossRef] [PubMed]

125. Pfeiffer, W.H.; McClafferty, B. HarvestPlus: Breeding Crops for Better Nutrition. Crop Sci. 2007, 47, S-88-S-105. [CrossRef]

126. Zhu, C.; Kobayashi, K.; Loladze, I.; Zhu, J.; Jiang, Q.; Xu, X.; Liu, G.; Seneweera, S.; Ebi, K.L.; Drewnowski, A.; et al. Carbon dioxide $\left(\mathrm{CO}_{2}\right)$ levels this century will alter the protein, micronutrients, and vitamin content of rice grains with potential health consequences for the poorest rice-dependent countries. Sci. Adv. 2018, 4, eaaq1012. [CrossRef] [PubMed]

127. Pilbeam, D.J. Breeding crops for improved mineral nutrition under climate change conditions. J. Exp. Bot. 2015, 66, 3511-3521. [CrossRef] [PubMed]

128. St. Clair, S.B.; Lynch, J.P. The opening of Pandora's Box: Climate change impacts on soil fertility and crop nutrition in developing countries. Plant Soil 2010, 335, 101-115.

129. White, P.J.; Broadley, M.R. Biofortifying crops with essential mineral elements. Trends Plant Sci. 2005, 10, 586-593. [CrossRef] [PubMed]

130. Friesen, M.L.; Porter, S.S.; Stark, S.C.; Wettberg, E.J.V.; Sachs, J.L.; Martinez-Romero, E. Microbially Mediated Plant Functional Traits. Ann. Rev. Ecol. Evol. Syst. 2011, 42, 23-46. [CrossRef]

131. Ramírez-Flores, M.R.; Rellán-Álvarez, R.; Wozniak, B.; Gebreselassie, M.-N.; Jakobsen, I.; Olalde-Portugal, V.; Baxter, I.; Paszkowski, U.; Sawers, R.J.H. Co-ordinated Changes in the Accumulation of Metal Ions in Maize (Zea mays ssp. mays L.) in Response to Inoculation with the Arbuscular Mycorrhizal Fungus Funneliformis mosseae. Plant Cell Physiol. 2017, 58, 1689-1699.

132. Lundberg, D.S.; Lebeis, S.L.; Paredes, S.H.; Yourstone, S.; Gehring, J.; Malfatti, S.; Tremblay, J.; Engelbrektson, A.; Kunin, V.; Rio, T.G.D.; et al. Defining the core Arabidopsis thaliana root microbiome. Nature 2012, 488, 86-90. [CrossRef] [PubMed]

133. Berg, G.; Grube, M.; Schloter, M.; Smalla, K. Unraveling the plant microbiome: Looking back and future perspectives. Front. Microbiol. 2014, 5, 148. [CrossRef] [PubMed]

134. Hirsch, P.R.; Mauchline, T.H. Who's who in the plant root microbiome? Nat. Biotechnol. 2012, 30, 961-962. [CrossRef] [PubMed]

135. Bouffaud, M.L.; Marie-Andrée, P.; Daniel, M.; Yvan, M.L. Root microbiome relates to plant host evolution in maize and other Poaceae. Environ. Microbiol. 2014, 16, 2804-2814. [CrossRef] [PubMed] 
136. Bulgarelli, D.; Garrido-Oter, R.; Münch, P.C.; Weiman, A.; Dröge, J.; Pan, Y.; McHardy, A.C.; Schulze-Lefert, P. Structure and Function of the Bacterial Root Microbiota in Wild and Domesticated Barley. Cell Host Microbe 2015, 17, 392-403. [CrossRef] [PubMed]

137. Pérez-Jaramillo, J.E.; Mendes, R.; Raaijmakers, J.M. Impact of plant domestication on rhizosphere microbiome assembly and functions. Plant Mol. Biol. 2016, 90, 635-644. [CrossRef] [PubMed]

138. Hartman, K.; van der Heijden, M.G.A.; Wittwer, R.A.; Banerjee, S.; Walser, J.-C.; Schlaeppi, K. Cropping practices manipulate abundance patterns of root and soil microbiome members paving the way to smart farming. Microbiome 2018, 6, 14. [CrossRef] [PubMed]

139. Dulloo, M.E.; Thormann, I.; Fiorino, E.; De Felice, S.; Rao, V.R.; Snook, L. Trends in Research using Plant Genetic Resources from Germplasm Collections: From 1996 to 2006. Crop Sci. 2013, 53, 1217-1227. [CrossRef]

140. Hajjar, R.; Hodgkin, T. The use of wild relatives in crop improvement: A survey of developments over the last 20 years. Euphytica 2007, 156, 1-13. [CrossRef]

141. Maxted, N.; Kell, S. Establishment of a Global Network for the In Situ Conservation of Crop Wild Relatives: Status and Needs; FAO Commission: Rome, Italy, 2009.

142. Castañeda-Álvarez, N.P.; Khoury, C.K.; Achicanoy, H.A.; Bernau, V.; Dempewolf, H.; Eastwood, R.J.; Guarino, L.; Harker, R.H.; Jarvis, A.; Maxted, N.; et al. Global conservation priorities for crop wild relatives. Nat. Plants 2016, 2, 16022. [CrossRef] [PubMed]

143. Larkan, N.J.; Lydiate, D.J.; Parkin, I.A.; Nelson, M.N.; Epp, D.J.; Cowling, W.A.; Rimmer, S.R.; Borhan, M.H. The Brassica napus blackleg resistance gene LepR3 encodes a receptor-like protein triggered by the Leptosphaeria maculans effector AVRLM1. New Phytol. 2013, 197, 595-605. [CrossRef] [PubMed]

144. Havey, M.J. The Use of Cytoplasmic Male Sterility for Hybrid Seed Production. In Molecular Biology and Biotechnology of Plant Organelles: Chloroplasts and Mitochondria; Daniell, H., Chase, C., Eds.; Springer: Dordrecht, The Netherlands, 2004; pp. 623-634.

145. Štorchová, H. The Role of Non-Coding RNAs in Cytoplasmic Male Sterility in Flowering Plants. Int. J. Mol. Sci. 2017, 18, 2429. [CrossRef] [PubMed]

146. McCouch, S.; Sweeney, M.; Li, J.; Jiang, H.; Thomson, M.; Septiningsih, E.; Edwards, J.; Moncada, P.; Xiao, J.; Garris, A.; et al. Through the genetic bottleneck: O. rufipogon as a source of trait-enhancing alleles for O. sativa. Euphytica 2007, 154, 317-339. [CrossRef]

147. Huang, B.E.; George, A.W.; Forrest, K.L.; Kilian, A.; Hayden, M.J.; Morell, M.K.; Cavanagh, C.R. A multiparent advanced generation inter-cross population for genetic analysis in wheat. Plant Biotechnol. J. 2012, 10, 826-839. [CrossRef] [PubMed]

148. Yu, J.; Holland, J.B.; McMullen, M.D.; Buckler, E.S. Genetic Design and Statistical Power of Nested Association Mapping in Maize. Genetics 2008, 178, 539-551. [CrossRef] [PubMed]

149. Tanksley, S.D.; Nelson, J.C. Advanced backcross QTL analysis: A method for the simultaneous discovery and transfer of valuable QTLs from unadapted germplasm into elite breeding lines. Theor. Appl. Genet. 1996, 92, 191-203. [CrossRef] [PubMed]

150. Lipka, A.E.; Kandianis, C.B.; Hudson, M.E.; Yu, J.; Drnevich, J.; Bradbury, P.J.; Gore, M.A. From association to prediction: Statistical methods for the dissection and selection of complex traits in plants. Curr. Opin. Plant Biol. 2015, 24, 110-118. [CrossRef] [PubMed]

151. Tanksley, S.D.; McCouch, S.R. Seed banks and molecular maps: Unlocking genetic potential from the wild. Science 1997, 277, 1063-1066. [CrossRef] [PubMed]

152. Berger, J.D.; Clements, J.C.; Nelson, M.N.; Kamphuis Lars, G.; Singh Karam, B.; Buirchell, B. The essential role of genetic resources in narrow-leafed lupin improvement. Crop Pasture Sci. 2013, 64, 361-373. [CrossRef]

153. Friesen, M.L.; von Wettberg, E.J. Adapting genomics to study the evolution and ecology of agricultural systems. Curr. Opin. Plant Biol. 2010, 13, 119-125. [CrossRef] [PubMed]

154. Smýkal, P.; Kenicer, G.; Flavell, A.J.; Corander, J.; Kosterin, O.; Redden, R.J.; Ford, R.; Coyne, C.J.; Maxted, N.; Ambrose, M.J.; et al. Phylogeny, phylogeography and genetic diversity of the Pisum genus. Plant Genet. Resour. 2011, 9, 4-18. [CrossRef]

155. Ogutcen, E.; Ramsey, L.; von Wettberg, E.; Bett, K. An exome capture array for lentil, Lens culinaris. Appl. Plant Sci. 2018, in press.

156. Bernardo, R.; Yu, J. Prospects for Genomewide Selection for Quantitative Traits in Maize. Crop Sci. 2007, 47, 1082-1090. [CrossRef] 
157. Desta, Z.A.; Ortiz, R. Genomic selection: Genome-wide prediction in plant improvement. Trends Plant Sci. 2014, 19, 592-601. [CrossRef] [PubMed]

158. Roorkiwal, M.; Rathore, A.; Das, R.R.; Singh, M.K.; Jain, A.; Srinivasan, S.; Gaur, P.M.; Chellapilla, B.; Tripathi, S.; Li, Y.; et al. Genome-Enabled Prediction Models for Yield Related Traits in Chickpea. Front. Plant Sci. 2016, 7, 1666. [CrossRef] [PubMed]

159. Spindel, J.; Begum, H.; Akdemir, D.; Virk, P.; Collard, B.; Redoña, E.; Atlin, G.; Jannink, J.-L.; McCouch, S.R. Genomic Selection and Association Mapping in Rice (Oryza sativa): Effect of Trait Genetic Architecture, Training Population Composition, Marker Number and Statistical Model on Accuracy of Rice Genomic Selection in Elite, Tropical Rice Breeding Lines. PLoS Genet. 2015, 11, e1004982.

160. Zhang, X.; Pérez-Rodríguez, P.; Burgueño, J.; Olsen, M.; Buckler, E.; Atlin, G.; Prasanna, B.M.; Vargas, M.; San Vicente, F.; Crossa, J. Rapid Cycling Genomic Selection in a Multiparental Tropical Maize Population. G3 Genes Genomes Genet. 2017, 7, 2315-2326. [CrossRef] [PubMed]

161. Dirzo, R.; Raven, P.H. Global State of Biodiversity and Loss. Ann. Rev. Environ. Resour. 2003, 28, $137-167$. [CrossRef]

162. Schöngart, J.; Rogério, G.; Sinomar, F.d.F.J.; Torbjørn, H. Age and Growth Patterns of Brazil Nut Trees (Bertholletia excelsa Bonpl.) in Amazonia, Brazil. Biotropica 2015, 47, 550-558. [CrossRef]

163. Singh, J.; Kalberer, S.R.; Belamkar, V.; Assefa, T.; Nelson, M.N.; Farmer, A.D.; Blackmon, W.J.; Cannon, S.B. A transcriptome-SNP-derived linkage map of Apios americana (potato bean) provides insights about genome re-organization and synteny conservation in the phaseoloid legumes. Theor. Appl. Genet. 2018, 131, 333-351. [CrossRef] [PubMed]

164. Schlautman, B.; Barriball, S.; Ciotir, C.; Herron, S.; Miller, A. Perennial Grain Legume Domestication Phase I: Criteria for Candidate Species Selection. Sustainability 2018, 10, 730. [CrossRef]

165. Zsögön, A.; Cermak, T.; Voytas, D.; Peres, L.E.P. Genome editing as a tool to achieve the crop ideotype and de novo domestication of wild relatives: Case study in tomato. Plant Sci. 2017, 256, 120-130. [CrossRef] [PubMed]

166. Castro, S.; Silveira, P.; Pereira, C.A.; Figueiredo, E. Systematic studies in Tylosema (Leguminosae). Bot. J. Linn. Soc. 2005, 147, 99-115. [CrossRef]

167. Sinou, C.; Forest, F.; Lewis, G.P.; Bruneau, A. The genus Bauhinia s.l. (Leguminosae): A phylogeny based on the plastid trnL-trnF region. Botany 2009, 87, 947-960. [CrossRef]

168. Jackson, J.C.; Duodu, K.G.; Holse, M.; Lima de Faria, M.D.; Jordaan, D.; Chingwaru, W.; Hansen, A.; Cencic, A.; Kandawa-Schultz, M.; Mpotokwane, S.M.; et al. The Morama Bean (Tylosema esculentum): A Potential Crop for Southern Africa. In Advances in Food and Nutrition Research; Taylor, S.L., Ed.; Academic Press: Cambridge, MA, USA, 2010; Volume 61, pp. 187-246.

169. Chingwaru, W.; Majinda, R.T.; Yeboah, S.O.; Jackson, J.C.; Kapewangolo, P.T.; Kandawa-Schulz, M.; Cencic, A. Tylosema esculentum (Marama) Tuber and Bean Extracts Are Strong Antiviral Agents against Rotavirus Infection. Evid. Based Complement. Altern. Med. 2011, 2011, 11. [CrossRef] [PubMed]

170. Van Wyk, B.E. The potential of South African plants in the development of new medicinal products. S. Afr. J. Bot. 2011, 77, 812-829. [CrossRef]

171. Keegan, A.; van Staden, J. Marama Bean, Tylosema esculentum, a plant worthy of cultivation. Sci. Afr. J. Sci. 1981, 77, 387.

172. Lompo, D.; Vinceti, B.; Gaisberger, H.; Konrad, H.; Duminil, J.; Ouedraogo, M.; Sina, S.; Geburek, T. Genetic conservation in Parkia biglobosa (Fabaceae: Mimosoideae)—What do we know? Silvae Genet. 2017, 66, 1-8. [CrossRef]

173. Varshney, R.K.; Close, T.J.; Singh, N.K.; Hoisington, D.A.; Cook, D.R. Orphan legume crops enter the genomics era! Curr. Opin. Plant Biol. 2009, 12, 202-210. [CrossRef] [PubMed]

174. Dempewolf, H.; Eastwood, R.J.; Guarino, L.; Khoury, C.K.; Müller, J.V.; Toll, J. Adapting Agriculture to Climate Change: A Global Initiative to Collect, Conserve, and Use Crop Wild Relatives. Agroecol. Sustain. Food Syst. 2014, 38, 369-377. [CrossRef] 
175. Maxted, N.; Avagyan, A.; Frese, L.; Iriondo, J.M.; Magos Brehm, J.; Singer, A.; Kell, S.P. ECPGR Concept for in Situ Conservation of Crop Wild Relatives in Europe; FAO Commission: Rome, Italy, 2015.

176. Castañeda-Álvarez, N.P.; Khoury, C.K.; Sosa, C.C.; Achicanoy, H.A.; Bernau, V.; Vincent, H.; Jarvis, A.; Struik, P.C.; Maxted, N. The distributions and ex situ conservation of crop wild relatives: A global approach. In Enhancing Crop Genepool Use: Capturing Wild Relative and Landrace Diversity for Crop Improvement; Maxted, N., Dulloo, M.E., Ford-Lloyd, B.V., Eds.; CABI: Wallingford, UK, 2016. 